\title{
The occurrence of progesterone $5 \beta$ - reductase is not limited to the angiosperms: a functional gene was identified in Picea sitchensis and expressed in Escherichia coli
}

\author{
Kristin Rudolph ${ }^{1}$, Thomas Wiegert ${ }^{2}$, Roland Schubert ${ }^{2}$ and Frieder Müller-Uri ${ }^{*}$
}

\begin{abstract}
Background: Progesterone $5 \beta$-reductases (P5ßRs) catalyse one step in the stereospecific biosynthesis of cardenolides (potent repellents of herbivores and pharmaceutical stimulants of disordered heart muscle cells). They were originally discovered in the genus Digitalis and have since been frequently isolated from other angiosperms. Recombinant P5ßRs engineered in Escherichia coli host cells convert a broad spectrum of compounds in vitro, sometimes with higher efficiency than with progesterone. This observation suggests additional functions for cardenolide metabolism and promises future use in sustainable chemistry and biotechnology.

Methods: A tissue complementary DNA (cDNA) library was screened for orthologous P5ßRs. Candidates were subcloned into expression vectors and overexpressed in E. coli cells. The recombinant P5ßR protein was investigated for catalytic activity with several related substrates. Using spectrophotometric assays, the biochemical parameters of the enzyme were calculated. A 3D model was created and was compared to the previously published P5ßR structure of Digitalis lanata and other plant P5ßR models.

Results: Performing protein similarity searches in public databases and comparison of 3D protein structure models revealed four CDNA clones in a tissue library of Picea sitchensis (Bong.) Carrière putatively encoding P5BRs. Succeeding with the expression of one clone in E. coli, the highly purified protein was unambiguously able to enantioselectively convert progesterone into 5ß-pregnane-3,20-dione. However, the catalytic activity to reduce the small molecule 2-cyclohexen-1-one was nearly 100 times faster. Methyl vinyl ketone was reduced similar to results from previously studied angiosperm resources.

Conclusions: (i) The low catalytic efficiency for progesterone conversion agrees with the fact that conifers have not been reported to accumulate cardenolides. This finding suggests that alternate metabolic processes occur whereby the newly detected enzymes could transform smaller molecules rather than large ones such as progesterone. (ii) An ancient P5ßR gene appears to have existed in the last common ancestor of seed plants approximately 300 million years ago. If the diversification of P5ßRs, including the currently detected homologous iridoid synthase activity, was related to stress encountered during the transition to growth on land, then investigation of P5ßRs from pteridophytes and bryophytes should improve our knowledge of this enzyme class and elucidate the direction of evolution.
\end{abstract}

Keywords: Progesterone $5 \beta$-reductase, Expression, Substrate specificity, Pinaceae

\footnotetext{
* Correspondence: frieder.mueller-uri@fau.de

${ }^{1}$ Chair of Pharmaceutical Biology, Department of Biology, Friedrich-Alexander

University of Erlangen-Nuremberg, Staudtstr. 5, 91058 Erlangen, Germany

Full list of author information is available at the end of the article
}

\section{Springer}

(c) 2016 Rudolph et al. Open Access This article is distributed under the terms of the Creative Commons Attribution 4.0 International License (http://creativecommons.org/licenses/by/4.0/), which permits unrestricted use, distribution, and reproduction in any medium, provided you give appropriate credit to the original author(s) and the source, provide a link to the Creative Commons license, and indicate if changes were made. 


\section{Background}

Cardenolides are known to repel herbivores and are traditionally used in human medicine as a heart stimulant (Agrawal et al. 2012). They are a group of glycosylated steroidal compounds that occur in numerous families of angiosperms (Luckner and Wichtl 2000) and are frequently detected in dicotyledonous species (reviewed by Kreis and Müller-Uri 2010), e.g. the rosids (Crossosomatales; Myrtales; Celastrales; Malpighiales; Fabales; Rosales; Brassicales; Malvales) or the asterids (Gentianales; Lamiales; Solanales; Asterales). Cardenolides have also been reported from derived monocots (Poales; Asparagales; Liliales) as well as from ancestral eudicots (Ranunculales). This distribution suggests that cardenolides arise from genes that were already present during the early diversification of angiosperms (Krenn and Kopp 1998; Luckner and Wichtl 2000). Tarrio et al. (2011) claimed that they were probably spread by horizontal gene transfer between protobacteria and plant cells. On the basis of genomic evidence from pines (Gavidia et al. 2007), we assume that homologous genes existed in plant genomes prior to the evolutionary split of angiosperms and gymnosperms. However, this hypothesis must be regarded as unproved until it has been verified by acceptable enzymatic evidence.

Progesterone 5ß-reductase (P5ßR) controls chiral cardenolide biosynthesis because it reduces progesterone via hydride transfer and protonation exclusively to $5 ß$-pregnane-3,20-dione (Fig. 1; for the detailed mechanism of this stereo-selective 1-4 hydrogen addition, see Thorn et al. 2008), whereas no $5 \alpha$-pregnane-3,20-dione has been found (Gärtner et al. 1990). Related enzymes have been detected in other plant species that do not accumulate cardenolides, following the initial purification of P5ßR activity from Digitalis purpurea L. by Gärtner et al. 1994. However, the identification of the resulting biochemical products remains a challenge (Herl et al. 2006, 2009; Gavidia et al. 2007; Bauer et al. 2010; Perez-Bermudez et al. 2010; Munkert et al. 2011, 2015a, 2015; Ernst et al. 2015).
All P5ßR enzymes isolated from plants belong to the short-chain dehydrogenase/reductase (SDR) superfamily (Kavanagh et al. 2008). They contain three highly conserved N-terminal protein motifs (I to III) responsible for binding the co-substrate NADPH. Because other standard SDR motifs are missing, plant P5ßR proteins represent a distinct SDR class (Thorn et al. 2008).

Five additional conserved amino acid motifs (IV to VIII), positioned towards the C-terminal protein half, have been discovered by sequence alignments, 3D modelling, and site-directed mutagenesis. These motifs play an important role in the molecular architecture including substrate binding and catalysis (Gavidia et al. 2007; Thorn et al. 2008; Perez-Bermudez et al. 2010; Bauer et al. 2010, 2012).

It is noteworthy that the expression of some P5ßR genes by plants is enhanced following wounding or in response to other stresses, such as increased mannitol concentration (Yang et al. 1997). However, P5ßR has been constitutively expressed at basal levels in all plant organs examined (Herl et al. 2009; Munkert et al. 2011). This pattern of expression can result from P5ßR encoding gene duplications, which gives rise to different regulated genes. Such an effect has been recently observed in Catharanthus roseus (L.) G. Don and Medicago truncatula Gaertn. (Munkert et al. 2015). In addition to single-stress defence reactions, it is possible that there is a fundamental role for P5ßR enzymes during plant development because an Arabidopsis thaliana (L.) Heynh. mutant has an abnormal leaf vein pattern (VEP) (Jun et al. 2002).

P5ßR enzymes are also promising tools for carrying out biotransformation (a current approach has been described by Durchschein et al. 2012) because they reduce in vitro a broad variety of molecules bearing an activated $\mathrm{C}=\mathrm{C}$ double bond, such as monocyclic enones (e.g. 2-cyclohexen-1-one, as shown in Fig. 1) or acyclic enoate esters (e.g. ethyl acrylate). In some cases, these reactions occur with higher efficiencies

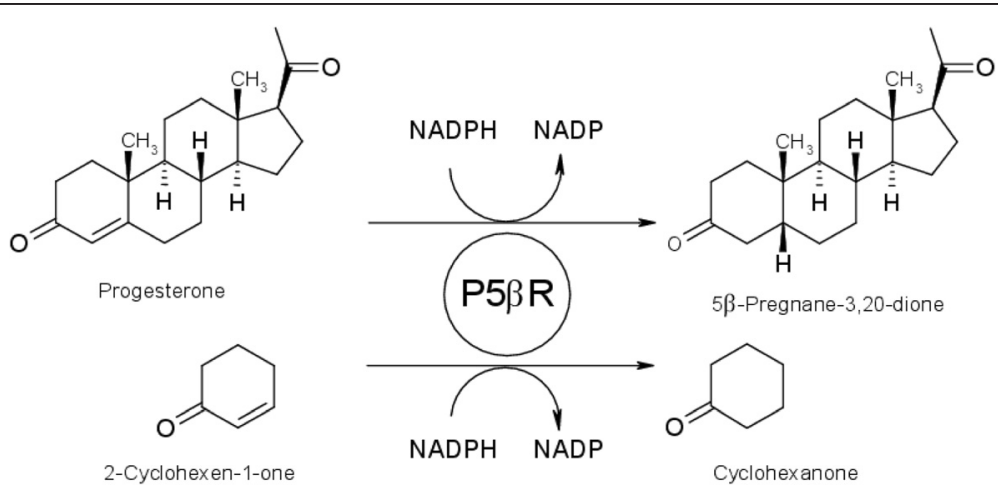

Fig. 1 Scheme of P5ßR reactions using progesterone or 2-cyclohexen-1-one as a substrate and NADPH as the co-substrate 
than for progesterone (Burda et al. 2009; Reß et al. 2015).

This study identified P5ßR enzymes in conifer tree species, where such proteins have not previously been detected unambiguously. Initial testing of substrate specificity and catalytic efficiency was also undertaken.

\section{Methods}

\section{Protein similarity searches and in silico analyses}

Current releases of non-redundant databases were screened by the protein blast algorithm operating at the public NCBI server (www.ncbi.nlm.nih.gov/Blastp) to search for P5ßR sequences in conifers. For this purpose, the P5ßR sequence (AIF73578.1) from Digitalis lanata Ehrh. was used as a query target. A multiple alignment was carried out by the ClustalW software package maintained on a local computer (Larkin et al. 2007) in order to inspect the conifer sequences for the presence of the conserved protein motifs characterizing plant P5ßR proteins. Molecular weights for the native conifer proteins and for the recombinant hybrid proteins were estimated by a peptide mass calculator software (www.peptidesynthetics.co.uk). Alpha-helical protein regions and $\beta$-sheets were identified by current computational methods (www.swissmodel.expasy.org).

\section{Modelling 3D protein structures}

SWISS-MODEL (Kiefer et al. 2009), a fully automated software package running on a public server (www.swissmodel.expasy.org), was employed to compute the three-dimensional structure of protein ABK24388.1. The previously determined crystal structure PDB ID: 2V6G (Thorn et al. 2008) of a recombinant P5ßR protein from $D$. lanata in a complex with the co-substrate $\mathrm{NADPH}$ served as the starting structure to make the model. Progesterone was placed manually into the active protein site. A stereo representation was drawn using the PyMOL Molecular Graphics System programme (Version 1.5.0.4 Schrödinger, LLC). This procedure was also used to calculate and draw the three-dimensional protein structures of orthologous P5ßR sequences from $A$. thaliana (AAL32529.1) and Erysimum crepidifolium Rchb. (ADG56544.1), respectively.

\section{DNA cloning into an Escherichia coli host vector}

We designed the forward primer 5 '-ggccatggatcctggtattcctggtggacaggttcc- $3^{\prime}$ and the reverse primer $5^{\prime}$ ggccataagcttctaaggaacgatattagatgacctg-3' (produced by biomers.net $\mathrm{GmbH}$, Ulm, Germany) for a PCR-based amplification $\left(5 \min 94{ }^{\circ} \mathrm{C}\right.$; $35 \times\left[30\right.$ s $94{ }^{\circ} \mathrm{C}$, 45 s $60{ }^{\circ} \mathrm{C}$, $2 \min 72{ }^{\circ} \mathrm{C}$; $7 \mathrm{~min} 72{ }^{\circ} \mathrm{C}$ ) of the plasmid clone WS02727_DO9 (provided by J. Bohlmann, Vancouver, Canada), which contains a full-length complementary DNA (cDNA) sequence encoding protein ABK24388.1 from Picea sitchensis (Bong.) Carrière (Sitka spruce) (Ralph et al. 2008). The underlined nucleotides did not anneal with the cDNA but created a unique BamHI site and a unique HindIII site, respectively, as indicated by the italicised letters. The 1.2-kb PCR product was digested with BamHI and HindIII and inserted into the expression plasmid pET28 M-SUMO3-GFP (provided by H. Besir, EMBL Protein Expression \& Purification Core Facility, Heidelberg, Germany), which had been previously cut with BamHI and HindIII to replace the EGFP reporter gene by the PCR product. All cloning steps including transformation (see below) were carried out as described by Sambrook and Russell (2001). The enzymes were obtained from Thermo Scientific Inc. (Waltham, MA). The resulting plasmid (pET28 MSUMO3-ABK24388.1) expresses a hybrid protein under the control of the T7 promoter with an N-terminus of six histidine residues fused in-frame with the ubiquitinrelated SUMO protein as well as the spruce protein. This N-terminal modification enhances the solubility of the recombinant protein in E. coli (Butt et al. 2005) and aids in its chromatographic separation (see below).

Transformed E. coli of strain BL21DE3/pLys (Promega, Mannheim, Germany) were selected on Luria-Bertani (LB) agar medium containing kanamycin $(20 \mathrm{mg} / \mathrm{L})$ and chloramphenicol $(10 \mathrm{mg} / \mathrm{L})$. The plasmid DNA was analysed by digestion with restriction enzymes. A bacterial clone harbouring the plasmid pET28 M-SUMO3ABK24388.1 was examined by the commercial LIGHTrun sequencing service (GATC Biotech, Köln, Germany) to confirm the correctness of the spruce nucleotide sequence.

\section{Recombinant protein production and purification}

Escherichia coli strain BL21DE3/pLysS, harbouring the plasmid pET28 M-SUMO3-ABK24388.1, was grown at $30{ }^{\circ} \mathrm{C}$ under rigorous shaking $(250 \mathrm{rpm})$ in 1 to $2 \mathrm{~L}$ of LB medium supplemented with kanamycin $(20 \mathrm{mg} / \mathrm{L})$ and chloramphenicol $(10 \mathrm{mg} / \mathrm{L})$. At an $\mathrm{OD}_{600}$ of 0.8 , IPTG was added to a final concentration of $1 \mathrm{mM}$. The culture was then incubated for $8 \mathrm{~h}$. Cells were harvested by centrifugation $\left(8.000 \times g, 30 \mathrm{~min}, 4{ }^{\circ} \mathrm{C}\right)$ and were suspended in $20 \mathrm{~mL}$ lysis buffer $\left(50 \mathrm{mM} \mathrm{NaH} \mathrm{PO}_{4}\right.$, $300 \mathrm{mM} \mathrm{NaCl}, 10 \mathrm{mM}$ imidazole, $\mathrm{pH}$ 8.0) containing a "complete" protease inhibitor cocktail as advised by the manufacturer (Roche Diagnostics, Mannheim, Germany). For cell disruption, a French-Press (Aminco, Sandy, UT) was used under internal pressure of 20.000 psi. Ni-NTA affinity chromatography was carried out using a standard procedure (Qiagen GmbH, Hilden, Germany). Eluted protein was mixed with $1 / 10$ volume of protease His6-SenP2 $(125 \mathrm{ng} / \mathrm{mL})$ previously purified from the strain E. coli BL21DE3/pLysS/pETM11-SenP2 (provided by H. Besir, EMBL Protein Expression \& Purification Core Facility, Heidelberg). The mixture was maintained for $30 \mathrm{~min}$ at 
$37{ }^{\circ} \mathrm{C}$, then tenfold diluted with $20 \mathrm{mM}$ Tris $/ \mathrm{HCl}(\mathrm{pH}$ 8.0), and again subjected to Ni-NTA affinity chromatography. The flow-through was loaded onto an anionexchange chromatography column (Resource Q, GE Healthcare Europe GmbH, Freiburg, Germany), equilibrated with $20 \mathrm{mM}$ Tris/ $\mathrm{HCl}(\mathrm{pH} 8.0)$ at a flow rate of $1 \mathrm{~mL} / \mathrm{min}$ using an Äkta Purifier FPLC device (GE Healthcare). The protein was finally eluted over 20 column volumes by means of a linear salt gradient ( 0 to $500 \mathrm{mM} \mathrm{NaCl}$ ) in $20 \mathrm{mM}$ Tris/ $\mathrm{HCl}$ (pH 8.0). Fractions of the major protein peak were analysed by SDS-PAGE. Protein concentrations were estimated according to Bradford (1976).

\section{Enzymatic tests, including product identification}

Enzymes, substrates, co-substrates, and reference substances were provided by Sigma-Aldrich $\mathrm{GmbH}$ (Taufkirchen, Germany), except the recombinant P5ßR proteins produced by Munkert et al. (2011), Bauer et al. (2012), or reported here. Solvents were purchased from Carl Roth GmbH (Karlsruhe, Germany). Successful enzymatic conversion of progesterone $(0.3 \mathrm{mM})$ to $5 ß$ pregnane-3,20-dione was achieved at $40{ }^{\circ} \mathrm{C}$ in samples containing $0.2 \mathrm{mg} / \mathrm{mL}$ recombinant protein and a $\mathrm{NADPH}$ regenerating system, consisting of $6.4 \mathrm{mM}$ NADP, $32.1 \mathrm{mM}$ glucose-6-phosphate, and 42 nkat glucose-6-phosphate dehydrogenase as described by Herl et al. (2009). Heat-inactivated samples $(10 \mathrm{~min}$, $100{ }^{\circ} \mathrm{C}$ ) served as controls. After $12 \mathrm{~h}$, enzymatic reactions were terminated by the addition of $1000 \mu \mathrm{L}$ dichloromethane. After evaporation, the dry residue was dissolved in $50 \mu \mathrm{L}$ methanol. To perform thin-layer chromatography (TLC), up to $20 \mu \mathrm{L}$ was spotted onto silica gel $60 \mathrm{~F}_{254}$ plates (VWR International, Radnor, PA) and run by using an 80:18:2 $(v / v)$ mixture of dichloromethane, methanol, and water. The product formation was followed by Jensen-Kny detection (Jork 1990). The stereo-selective conversion of progesterone was examined from the remaining part after the evaporation of methanol and dissolving the residue again in $100 \mu \mathrm{L}$ dichloromethane. A volume of $3 \mu \mathrm{L}$ of this solution was used in gas chromatography-mass spectrometry (GC-MS) as described by Rudolph et al. (2014). To identify enzymatic products by TLC as well as GC-MS, the provided reference substances $5 ß$-pregnane-3,20dione, $5 \alpha$-pregnane-3,20-dione, and progesterone were tested alone.

To monitor the velocity of the reaction $\left(k_{\text {cat }}\right)$ during $200 \mathrm{~s}$ at $40{ }^{\circ} \mathrm{C}$ and to identify substrate concentrations associated with half-maximal velocity $\left(K_{\mathrm{M}}\right)$, conversion of NADPH $(0.4 \mathrm{mM})$ to NADP was recorded by a photometer $(340 \mathrm{~nm})$ in the presence of 0.05 to $0.4 \mathrm{mM}$ substrate (progesterone, 2-cyclohexen-1-one, or methyl vinyl ketone). Kinetic parameters were obtained from the Shimadzu UV Probe software package.

\section{Results and discussion \\ Protein alignment data}

We scanned the protein databases to search for P5ßR sequences amongst conifer species by a computational similarity search and detected a few tentatively identified tissue library cDNA clones that encoded 54 to $55 \%$ identical amino acids with the angiosperm target query. The identity of the corresponding proteins (ABK24243.1, ABK24388.1, ABR16676.1, and ABR16709.1 of $P$. sitchensis) ranged from 85 to $97 \%$, with ABK24243.1 and ABR16676.1 producing the best match. The four sequences shared eight conserved motifs characteristic for plant P5ßRs (Thorn et al. 2008; Perez-Bermudez et al. 2010). These motifs differ only slightly in comparison to the query. Motifs I, II, VI, VII, and VIII have one amino acid exchange each, motifs III and V show two individual variable positions, and motif IV has three amino acid replacements, as shown in Table 1. The alignment data suggest the existence of a homogeneous multi-gene family within the genome of Sitka spruce because the conifer proteins all encode 399 amino acids (one full-length sequence is shown in Fig. 2) and their individual molecular masses (45.3-45.4 kDa) range in size typical for plant P5ßRs. Such a family could provide in planta an enzymatic reduction of progesterone and related substrates. Small multi-gene families encoding P5ßR activities have been reported earlier for angiosperm species (Gavidia et al. 2007; Munkert et al. 2015a, 2015). We assume that an ancient gene was already present in the last common ancestor of gymnosperms and angiosperms approximately 300 million years ago, when the Coniferales appeared during the era of late Pennsylvanian era (Savard et al. 1994).

Gavidia et al. (2007) previously identified two pine genes in public databases using a similarity search programme (tblastn) and a P5ßR sequence from $D$. lanata. The authors used both entries to construct an unrooted phylogenetic tree with other plant species indicating poor bootstrap support $(51 \%)$ of the pine clade. We were unable to find either sequence again (their individual gene annotation numbers were not submitted) but acknowledge a striking similarity between spruce and pine with reference to both short diagnostic protein motifs.

\section{D structural protein modelling data}

A possible 3D structure was calculated for protein ABK24388.1 to provide proof of the sequence similarities. Our model (Fig. 3a) shows an N-terminal double Rossman fold responsible for co-substrate binding, which corresponds to the stretch of repeated $ß$-sheet 
Table 1 Picea protein motifs (I-VIII) compared to the consensus P5ßR sequence and a sequence from Digitalis lanata (D/P5ßR)

\begin{tabular}{|c|c|c|c|}
\hline & $D / P 5 \beta R$ & Picea sitchensis & Picea sitchensis \\
\hline \multirow[t]{3}{*}{$\overline{\text { Acc. Nr./consensus }}{ }^{a}$} & \multirow[t]{3}{*}{ AlF73578.1 } & \multirow[t]{3}{*}{ ABK24388.1 } & ABK24243.1 \\
\hline & & & ABK16676.1 \\
\hline & & & ABK16709.1 \\
\hline Motif I/GxxGxxG & GVTGIIGN & GVTGIVGN & GVTGIVGN \\
\hline Motif II/GxxRR & GVSRR & GVARR & GVARR \\
\hline Motif III/Dhx[cp] & DISD & DVLD & DVLD \\
\hline Motif IV/DhTHhFYYpW[hp] & DVTHVFYVTW & DVTHLFWWW & DVTHLFWWW \\
\hline Motif V/TgxKxYhG[hp] & TGRKHYMGP & TGGKHYLGP & TGAKHYLGP \\
\hline Motif VI/NFYYxxED & NFYYDLED & NFYYTLED & NFYYTLED \\
\hline Motif VII/Wp[VI]HPR & WSVHRP & WSIHRP & WSIHRP \\
\hline Motif VIII/D[hp]DlhA[ED] & $D A D \perp I A E$ & DAELIAE & DAELIAE \\
\hline
\end{tabular}

Amino acid variations amongst Picea proteins and to D/P5 $\beta$ R are indicated in bold. In the motifs, "c" denotes a charged residue, " $h$ " a hydrophobic residue, "p" a polar residue, and " $\mathrm{x}$ " any possible residue

aPerez-Bermudez et al. 2010

and $\alpha$-helix structural elements (Fig. 2) and is in agreement with data from other investigators (Thorn et al. 2008; Bauer et al. 2010, 2012). This region is connected to the hydrophobic substrate binding C-terminal domain positioned in the upper part of the model, which exclusively harbours the clustered helical amino acid stretches depicted in Fig. 2. A one-by-one comparison of the P5ßR protein models between $P$. sitchensis and two angiosperm species (Fig. 3b, c) revealed no striking differences.

\section{Recombinant protein purification data}

Escherichia coli was transformed with the plasmid pET28 M-SUMO3-ABK24388.1 to provide recombinant spruce protein for enzymatic investigations. A faint band at the expected $66.7-\mathrm{kDa}$ molecular weight was visible by SDS-PAGE (Fig. 4, lane 2; lane 1 presents size markers) indicating low production of the recombinant protein within the host cells. Using the N-terminal $6 \times$ His tag, this protein was successfully enriched by a $\mathrm{Ni}$ NTA chromatography and appeared afterwards as the most prominent band (Fig. 4, lane 3). Cleaving the $\mathrm{N}$ terminus tag with SenP protease and repeated chromatography (Fig. 4, lanes 4 to 6 ) lead to the isolation of a single recombinant protein band of $45.2 \mathrm{kDa}$. This pure recombinant protein lacks the first methionine residue in comparison to the native spruce polypeptide ABK24388.1 due to the cloning procedure and the protease cleavage. Approximately $10 \mathrm{mg}$ recombinant spruce protein was obtained from $2 \mathrm{~L}$ bacterial cultures.

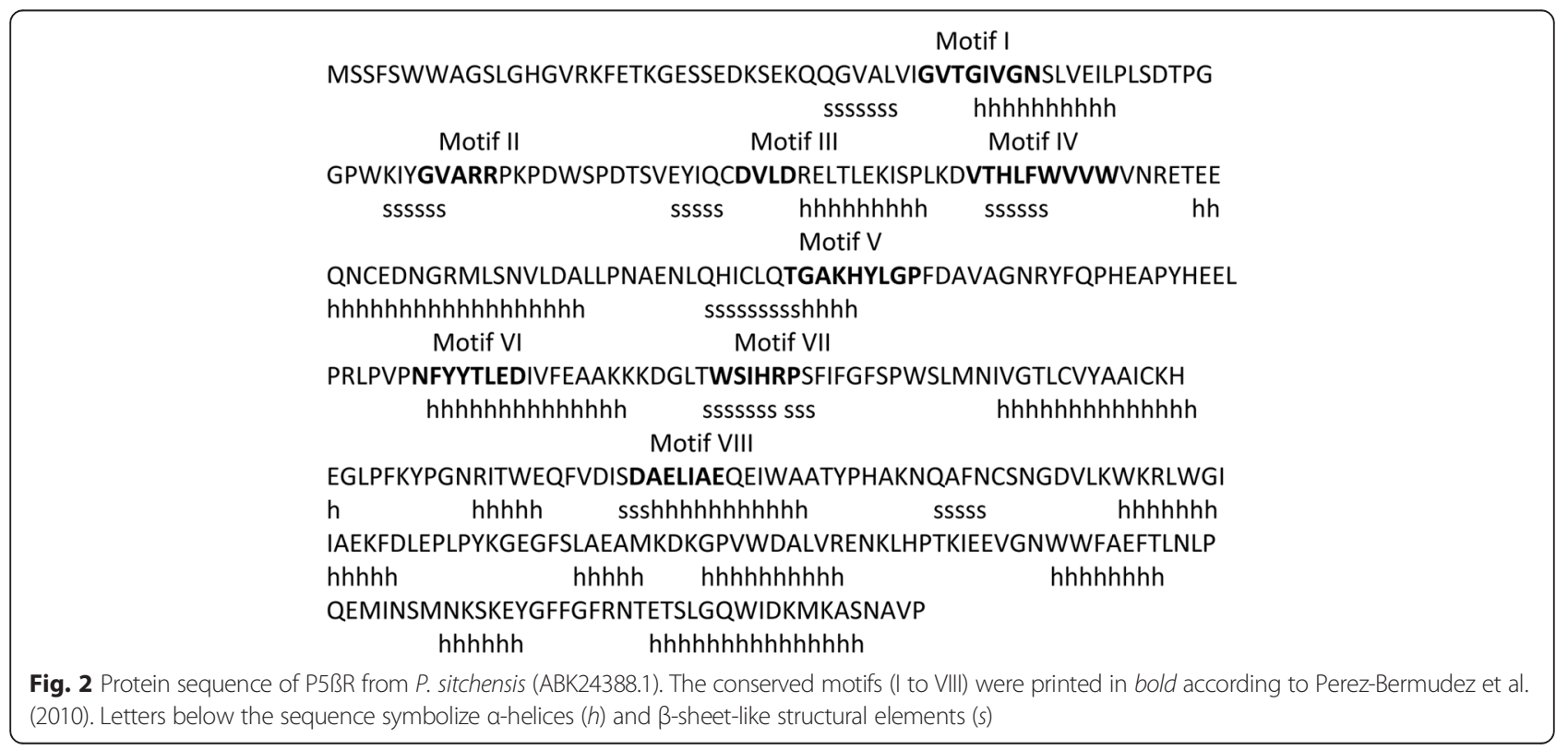



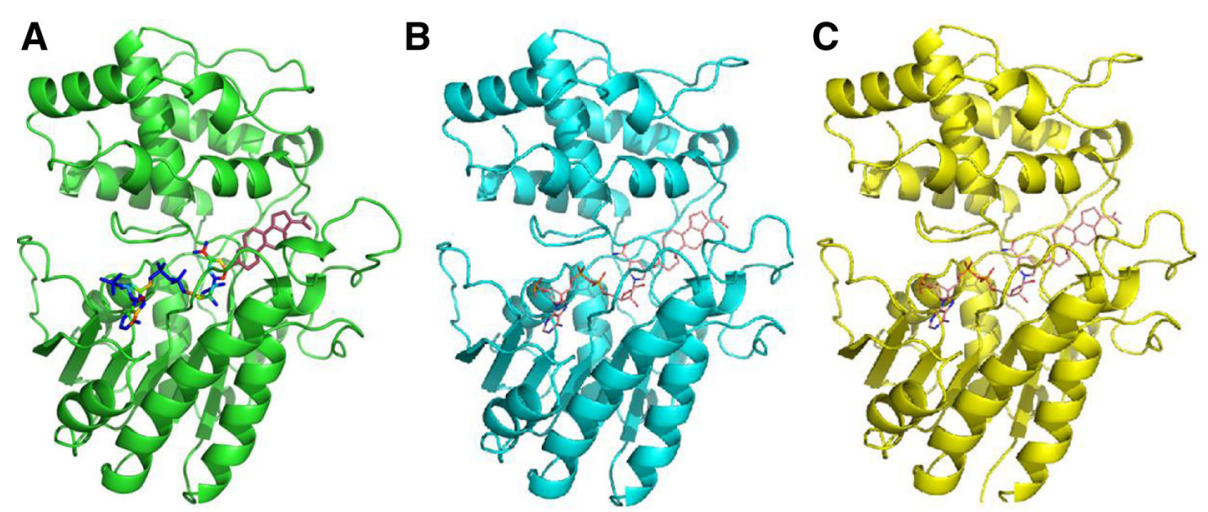

Fig. 3 Ribbon graphics representing the 3D structural protein data calculated for orthologous P5ßR enzymes from different species. a Protein ABK24388.1 from P. sitchensis. b Protein AAL32529.1 from A. thaliana. c Protein ADG56544.1 from E. crepidifolium

\section{Enzymatic data}

The highly purified recombinant spruce protein was able to convert progesterone into 5ß-pregnane-3,20-dione, indicating a genuine P5ßR enzyme activity, as shown by TLC analysis (Fig. 5) and analysis of the authentic sample by GC-MS (Fig. 6). This stereo-selective reaction

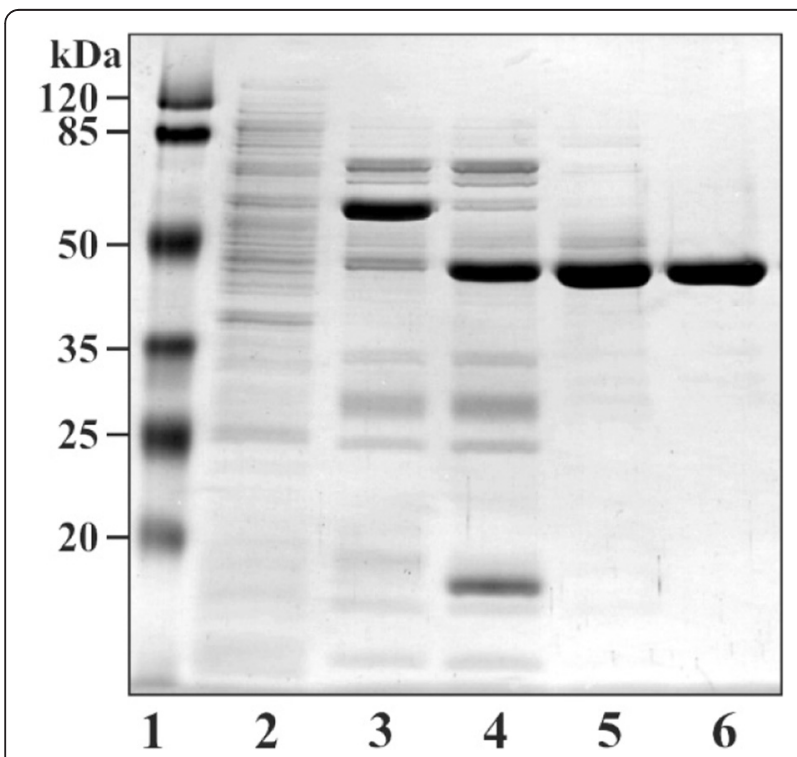

Fig. 4 Purification steps to isolate recombinant P $5 \beta R$ protein ABK24388.1 of $P$. sitchensis from E. coli host cells using an N-terminal $6 \times$ His tag SUMO protein fusion. Five micrograms of total protein per lane was analysed by a $12 \%$ SDS-PAGE. Lane 1: Standard proteins of indicated molecular weights (Thermo \#26612, Thermo Scientific, Darmstadt, Germany). Lane 2: Cell-free protein extract of E. coli BL21DE3/pLysS/ pET28 M-SUMO3-ABK24388.1 prepared $8 \mathrm{~h}$ after the addition of IPTG. Lane 3: Protein fraction eluted from the first Ni-NTA affinity column. Lane 4: Protein fraction eluted from the first Ni-NTA affinity column following incubation with SenP2 protease. Lane 5: Flow-through of the second Ni-NTA affinity column. Lane 6: Collected major peak fractions obtained after anion-exchange chromatography on a Resource Q column occurred more slowly than with either of the recombinant angiosperm enzymes tested, which produced greater amounts of 5ß-pregnane-3,20-dione under the same conditions (Fig. 5b, see lanes 1 and 2 vs. lane 4). However, $5 \alpha$-pregnane-3,20-dione was not formed by any of the enzymes studied and the conditions of the assays were always kept constant.

Exact kinetic values were determined by a photometrical assay measuring the conversion of the co-substrate NADPH into NADP. For the recombinant spruce enzyme, the data (Table 2) reveal a low catalytic efficiency $\left(k_{\mathrm{cat}} / K_{\mathrm{M}}\right)$ for the reduction of progesterone compared to recombinant angiosperm proteins studied by other investigators. This difference may be because only 11 out of the 17 conserved amino acid residues that are required for rapid catalytic action are present (Bauer et al. 2010; Petersen et al. 2015). The low catalytic efficiency associated with progesterone conversion increased 88.9 times when 2-cyclohexen-1-one was assessed. This molecule is smaller than progesterone and probably is a better fit for the catalytic site.

Enzymes are known to contain single residues controlling product building rates and functional evolution as analysed by $\mathrm{Li}$ et al. (2013). Tyrosine-156 (occurring in spruce as well), asparagine-205, and serine-248 were originally identified as hotspots responsible for the low catalytic efficiency reported for a recombinant P5ßR enzyme from $D$. lanata. Its catalytic performance was significantly improved in vitro after substituting asparagine in position 205 by methionine or alanine (Bauer et al. 2012).

The slow enzymatic reaction for progesterone in contrast to 2-cyclohexen-1-one agrees with the fact that spruce species have not been reported to accumulate cardenolides. This raises a question concerning a possible in planta function of the conifer proteins, which correspond in structure and origin to the P5ßR proteins 

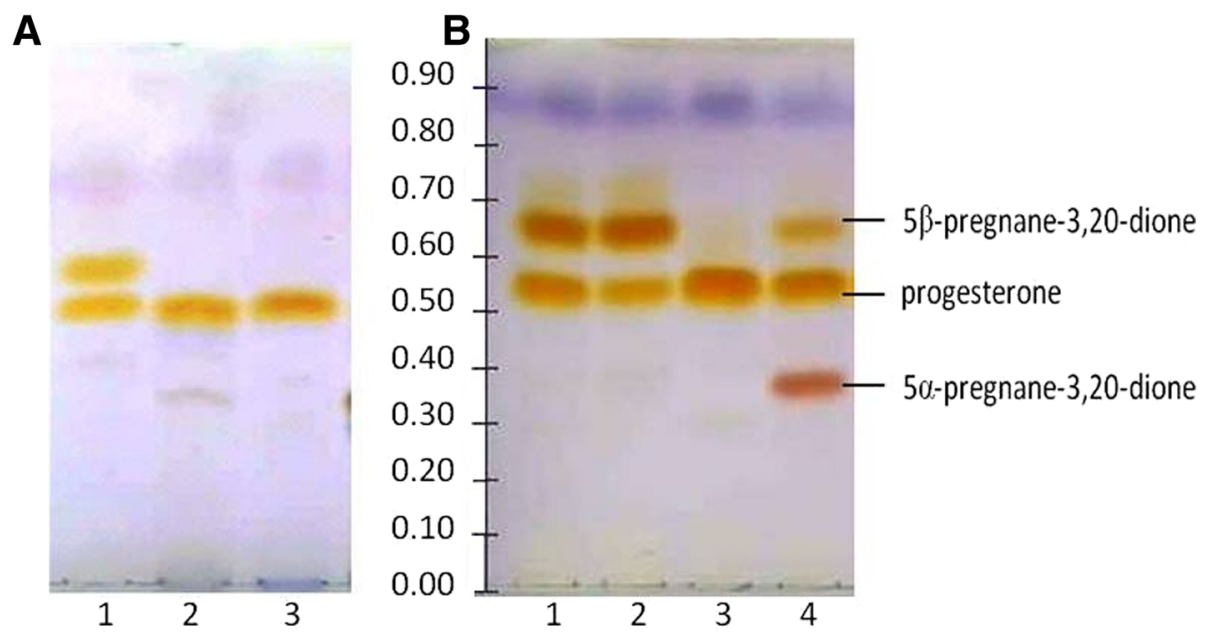

Fig. 5 Analysis of different P5ßR enzyme activities by TLC following a 12-h reaction time. a 5ß-Pregnane-3,20-dione band $\left(R_{f}=0.65\right)$ obtained from progesterone $\left(R_{f}=0.53\right)$ by the recombinant protein of $P$. sitchensis (lane 1$)$ compared to negative controls containing heat-inactivated spruce enzyme plus progesterone (lane 2) as well as a progesterone sample without enzyme (lane 3 ). $\mathbf{b}$ Identification of the reaction product, $5 \beta$-pregnane-3,20-dione $\left(R_{\mathrm{f}}=0.65\right)$, from progesterone $\left(R_{\mathrm{f}}=0.53\right)$ after testing recombinant protein of $A$. thaliana (lane 1$)$, Erysimum crepidifolium (lane 2), and P. sitchensis (lane 3: heat-inactivated enzyme sample; lane 4: reference 5a-pregnane-3,20-dione, $R_{\mathrm{f}}=0.40$, was added to the active enzymatic reaction as an internal control)

from angiosperms but do not prefer the same substrates, suggesting that they play a role in different metabolic pathways. Favouring small substrates, the spruce enzymes could reduce lipid derivatives (e.g. acrolein or methyl vinyl ketone) containing $\alpha, \beta$-unsaturated carbonyl groups. Such volatile substances of limited size were found to trigger the activation of a pathogenesis-related gene and genes involved in metabolism (Almeras et al. 2003). Our current enzymatic exploration (Table 2) indicates that the recombinant P5ßR of $P$. sitchensis reduces methyl vinyl ketone in vitro similar to a number of other enzymes from angiosperms.

Conifers also release a broad range of oleoresin terpenes during diverse defence reactions against herbivores and pathogens (for detailed information, see Zerbe and Bohlmann 2014). Amongst them, single molecules offer activated $\mathrm{C}=\mathrm{C}$ bonds next to carbonyl oxygen, which are likely applicable to an enzymatic reduction by

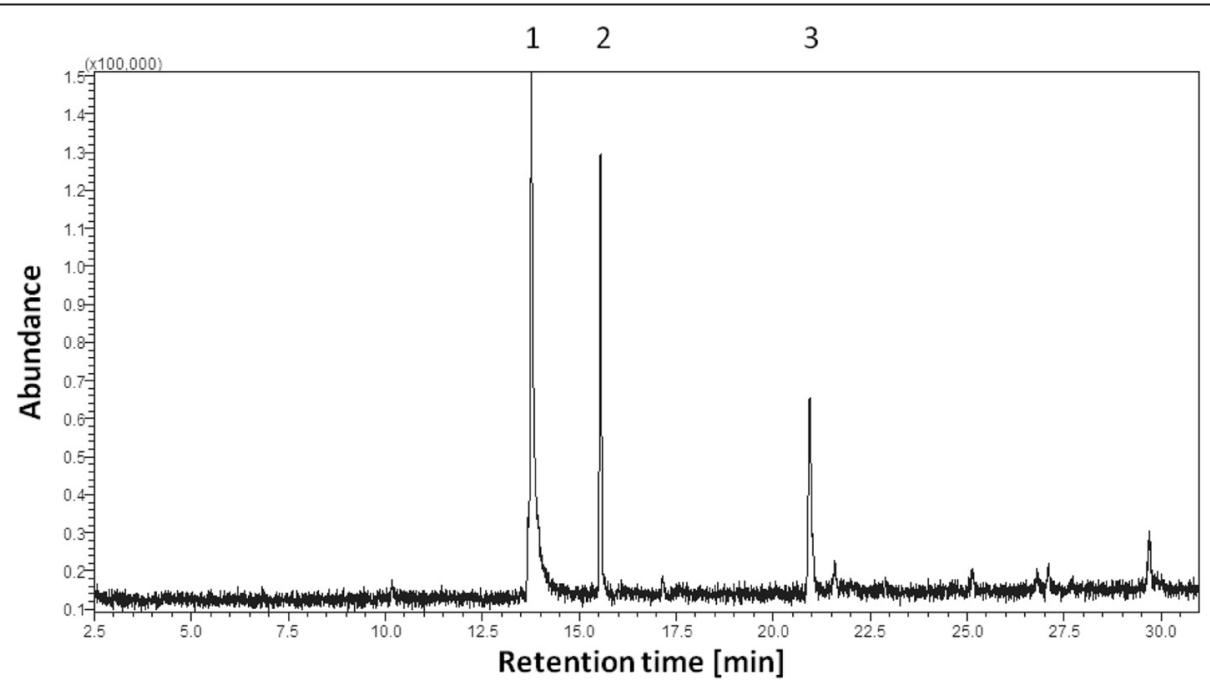

Fig. 6 GC-MS analysis of the enzymatic product obtained with recombinant P5ßR of $P$. sitchensis after a 12-h reaction time. The total ion chromatogram was generated from a sample aliquot previously studied by TLC (Fig. 5b, lane 4) and indicates 5ß-pregnane-3,20-dione (3; $R_{\mathrm{t}}=21.1 \mathrm{~min}$ ) originating from progesterone $\left(2 ; R_{\mathrm{t}}=15.5 \mathrm{~min}\right)$. The $5 \mathrm{a}$-pregnane-3,20-dione $\left(1 ; R_{\mathrm{t}}=13.8 \mathrm{~min}\right)$ was added to the active reaction as an internal control. It is not produced by enzymatic catalysis as shown in Fig. 5. Peak identification was possible because the substances were tested alone (not shown). Minor peaks do not represent pregnane-like compounds on the basis of a MS data comparison 
Table 2 A compilation of individual parameters of recombinant P5ßR enzymes from Picea sitchensis (rPsP5ßR), Arabidopsis thaliana (rAtP5ßR), Erysimum crepidifolium (rEcP5ßR), and Medicago truncatula (rMtP5ßR) with progesterone, 2-cyclohexen-1-one, and methyl vinyl ketone, respectively

\begin{tabular}{|c|c|c|c|c|c|}
\hline Enzyme & Substrate & $K_{M}(\mu M)$ & $k_{\text {cat }}\left(\min ^{-1}\right)$ & $k_{\text {cat }} / K_{M}\left(\min ^{-1} M^{-1}\right)$ & Preference \\
\hline \multirow[t]{3}{*}{$\operatorname{rPs} 55 \beta R$} & Progesterone & 111 & $0.59 \pm 0.02$ & 0.0053 & 88.9 \\
\hline & 2-Cyclohexen-1-one & 88 & $41.6 \pm 3.05$ & 0.4727 & \\
\hline & Methyl vinyl ketone & 75 & $6.0 \pm 0.25$ & 0.0800 & \\
\hline \multirow[t]{3}{*}{$\mathrm{rAtP} 5 \beta \mathrm{R}^{\mathrm{a}}$} & Progesterone & 268 & $10.11 \pm 2.99$ & 0.0373 & 15.5 \\
\hline & 2-Cyclohexen-1-one & 116 & $66.85 \pm 3.78$ & 0.5775 & \\
\hline & Methyl vinyl ketone & n.d. & n.d. & n.d. & \\
\hline \multirow[t]{3}{*}{$r E C P 5 \beta R^{b}$} & Progesterone & 77 & 0.60 & 0.0077 & 36.4 \\
\hline & 2-Cyclohexen-1-one & 518 & 147 & 0.2837 & \\
\hline & Methyl vinyl ketone & 344 & 43.8 & 0.1273 & \\
\hline \multirow[t]{3}{*}{$r M t P 5 \beta R^{c}$} & Progesterone & 144 & 30.0 & 0.2083 & 1.1 \\
\hline & 2-Cyclohexen-1-one & 82 & 19.2 & 0.2317 & \\
\hline & Methyl vinyl ketone & 136 & 32.4 & 0.2382 & \\
\hline
\end{tabular}

Substrate preference was calculated dividing $k_{\text {cat }} / K_{\mathrm{M}} 2$-cyclohexen-1-one by $k_{\text {cat }} / K_{\mathrm{M}}$ progesterone. The labelled values were taken from the indicated references. The results represent mean values based on three replications done n.d. not determined

${ }^{a}$ Bauer et al. 2012

${ }^{\mathrm{b}}$ Munkert et al. 2011

cMunkert et al. 2015

P5ßR activity. Geu-Flores et al. (2012) reported that P5ßR activity is expressed in $C$. roseus during the biosynthesis of a bicyclic monoterpene, namely the iridoid compound nepetalactol (Geu-Flores et al. 2012. Subsequently, it has been demonstrated that the precursor substance 8oxogeranial is converted in a NADPH-dependent manner by a number of recombinant P5ßR enzymes. This reaction was up to 1.300 times faster than the conversion of progesterone (Munkert et al. 2015). The authors therefore concluded that iridoid synthase activity is an intrinsic feature of all angiosperm P5ßR enzymes that evolved early during evolution. However, structural features currently distinguish iridoid synthase from its close homolog progesterone $5 \beta$-reductase (Kries et al. 2015, Alagna et al. 2015). The acceptance of 8-oxogeranial is not restricted to the angiosperms. We found a reaction using the recombinant spruce enzyme as well, which is not yet quantified due to our limited resources. Regarding the diverse catalytic actions, P5ßR was renamed recently as progesterone $5 \beta$-reductase/iridoid synthase (PRISE) by Petersen et al. (2015).

\section{Conclusions}

If plant P5ßR diversification was related to stress encountered during the transition of plants to growth on land as claimed by Jun et al. (2002), then the investigation of P5ßR proteins from lower plant species should significantly improve phylogenetic studies. Homologous genes from pteridophytes and bryophytes or genes from conifer species will then serve as outgroups to rebuild rooted phylogenetic trees inferring ancestral genes and derived genes, as well as the enzymatic reactions.

\section{Competing interests}

The authors declare that they have no competing interests.

Authors' contributions

All authors read and approved the final manuscript.

\section{Acknowledgements}

We thank J. Bohlmann (University of British Columbia, Vancouver, Canada) for the generous gift of the CDNA clone WS02727_D09 and H. Besir (EMBL, Heidelberg, Germany) for providing the plasmids PET28 M SUMO3-GFP and pET11 M-SenP2. The help of two anonymous peers and the editor in making this paper more accurate to read is acknowledged.

\section{Author details}

${ }^{1}$ Chair of Pharmaceutical Biology, Department of Biology, Friedrich-Alexander University of Erlangen-Nuremberg, Staudtstr. 5, 91058 Erlangen, Germany.

${ }^{2}$ Biotechnology Group, University of Applied Sciences Zittau/Görlitz,

Theodor-Körner-Allee 16, 02763 Zittau, Germany.

Received: 3 August 2015 Accepted: 18 February 2016

Published online: 10 March 2016

\section{References}

Agrawal, A. A., Petschenka, G., Bingham, R. A., Weber, M. G., \& Rasmann, S. (2012). Toxic cardenolides: chemical ecology and coevolution of specialized plantherbivore interactions. New Phytologist, 194, 28-45.

Alagna, F., Geu-Flores, F., Kries, H., Panara, F., Baldoni, L., O'Connor, S.E., \& Osbourn, A. (2015). Identification and characterization of the iridoid synthase involved in oleuropein biosynthesis in olive (Olea europaea) fruits. Journal Biological Chemistry, in press, jbc.M115.701276.

Almeras, E., Stolz, S., Vollenweider, S., Reymond, P., Mene-Saffrane, L., \& Farmer, E. E. (2003). Reactive electrophile species activate defense gene expression in Arabidopsis. Plant Journal, 34(2), 205-216.

Bauer, P., Munkert, J., Brydziun, M., Burda, E., Müller-Uri, F., Gröger, H., et al. (2010). Highly conserved progesterone $5 ß$-reductase genes (P5ßR) from $5 ß$ - 
cardenolide-free and 5ß-cardenolide-producing angiosperms. Phytochemistry, $71,1495-1505$.

Bauer, P., Rudolph, K., Müller-Uri, F., \& Kreis, W. (2012). Vein-patterning 1-encoded progesterone $5 ß$-reductase: activity-guided improvement of catalytic efficiency. Phytochemistry, 77, 53-59.

Bradford, M. M. (1976). A rapid and sensitive method for the quantitation of microgram quantities of protein utilizing the principle of protein-dye binding. Analytical Biochemistry, 72, 248-254.

Burda, E., Kraußer, M., Fischer, G., Hummel, W., Müller-Uri, F., Kreis, W., et al. (2009). Recombinant $\Delta^{4,5}$-steroid $5 ß$-reductases as biocatalysts for the reduction of activated $\mathrm{C}=\mathrm{C}$ double bonds in monocyclic and acyclic molecules. Advanced Synthesis \& Catalysis, 351, 2787-2790.

Butt, T. R., Edavettal, S. C., Hall, J. P., \& Mattern, M. R. (2005). SUMO fusion technology for difficult-to-express proteins. Protein Expression \& Purification, 43, 1-9.

Durchschein, K., Wallner, S., Macheroux, P., Schwab, W., Winkler, T., Kreis, W., et al. (2012). Nicotinamide-dependent ENE reductases as alternative biocatalysts for the reduction of activated alkenes. European Journal Organic Chemistry, 2012, 4963-4968.

Ernst, M., Munkert, J., Campa, M., Malnoy, M., Martens, S., \& Mueller-Uri, F. (2015). Steroid 5ß-reductase of Vitis vinifera: molecular cloning, expression and modelling. Journal Agriculture Food Chemistry, 63, 10112-10120.

Gavidia, I., Tarrio, R., Rodriguez-Trelles, F., Perez-Bermudez, P., \& Seitz, H. U. (2007). Plant progesterone $5 ß$-reductase is not homologous to the animal enzyme. Molecular evolutionary characterization of P5ßR from Digitalis purpurea. Phytochemistry, 68, 853-864.

Gärtner, D. E., Wendroth, S., \& Seitz, H. U. (1990). A stereo-specific enzyme of the putative biosynthetic pathway of cardenolides. Characterization of a progesterone 5ß-reductase from leaves of Digitalis purpurea L. FEBS Letters, 271, 239-242.

Gärtner, D. E., Keilholz, W., \& Seitz, H. U. (1994). Purification, characterization and partial peptide microsequencing of progesterone $5 \beta$-reductase from shoot cultures of Digitalis purpurea. European Journal of Biochemistry, 225, 1125-1132.

Geu-Flores, F., Sherden, N. H., Courdavault, V., Burlat, V., Glenn, W. S., Wu, G., et al. (2012). An alternative route to cyclic terpenes by reductive cyclization in iridoid biosynthesis. Nature, 492, 138-142.

Herl, V., Fischer, G., Bötsch, R., Müller-Uri, F., \& Kreis, W. (2006). Molecular cloning and expression of progesterone $5 ß$-reductase (5ß-POR) from Isoplexis canariensis. Planta Medica, 72, 1163-1165.

Herl, V., Fischer, G., Reva, V. A., Stibritz, M., Muller, Y. A., Müller-Uri, F., et al. (2009). The VEP1 gene (At4g24220) encodes a short-chain dehydrogenase/reductase with 3-oxo- $\Delta^{4,5}$-steroid-5ß-reductase activity in Arabidopsis thaliana L. Biochemie, 91, 517-525

Jork, H. (1990). Thin layer chromatography: Reagents and detection methods. In H. Jork, W. Funk, W. Fischer, \& H. Wimmer (Eds.), Thin-layer chromatography (Vol. 1, pp. 195-198). New York: VCH Publishers.

Jun, S. H., Ha, C. M., \& Nam, H. G. (2002). Involvement of the VEP1 gene in vascular strand development in Arabidopsis thaliana. Plant Cell Physiology, 43, 323-330.

Kavanagh, K. L., Jörnvall, H., Persson, B., \& Oppermann, U. (2008). Medium- and short-chain dehydrogenase/reductase gene and protein families. The SDR superfamily: functional and structural diversity within a family of metabolic and regulatory enzymes. Cellular \& Molecular Life Science, 65, 3895-3906.

Kiefer, F., Arnold, K., Künzli, M., Bordoli, L., \& Schwede, T. (2009). The SWISS-MODEL repository and associated resources. Nucleic Acids Research, 37, D387-D392.

Kries, H., Caputi, L., Stevenson, C. E. M., Okamileen, M., Sherden, N. H., Geu-Flores, F., et al. (2015). Structural determinants of reductive terpene cyclization in iridoid biosynthesis. Nature Chemical Biology, 12, 6-8.

Kreis, W., \& Müller-Uri, F. (2010). Biochemistry of sterols, cardiac glycosides, brassinosteroids, phytoecdysteroids and steroid saponins. In: M. Wink, (ed.) Biochemistry of Plant Secondary Metabolism. Annual Plant Reviews, 40, 304-363. CRC Press, Sheffield.

Krenn, L., \& Kopp, B. (1998). Bufadienolides from animal and plant sources. Phytochemistry, 48, 1-29.

Larkin, M. A., Blackshields, G., Brown, N. P., Chenna, R., McGettigan, P. A., McWilliam, H., et al. (2007). ClustalW and ClustalX version 2. Bioinformatics, 23, 2947-2948.

Li, J. X., Fang, X., Zhao, Q., Ruan, J. X., Yang, C. Q., Wang, L. J., et al. (2013). Rational engineering of plasticity residues of sesquiterpene synthases from Artemisia annua: product specificity and catalytic efficiency. Biochemical Journal, 451(3), 417-426.

Luckner, M., \& Wichtl, M. (2000). Digitalis. Germany: WV GmbH Stuttgart.
Munkert, J., Bauer, P., Müller-Uri, F., \& Kreis, W. (2011). Progesterone 5ß-reductase of Erysimum crepidifolium: cDNA cloning, expression in Escherichia coli and reduction of enones with the recombinant protein. Phytochemistry, 72, 1710-1717.

Munkert, J., Pollier, J., Miettinen, K., Van Moerkercke, A., Payne, R., Müller-Uri, F., et al. (2015). Iridoid synthase activity is common among the plant progesterone 53-reductase family. Molecular Plant, 8(1), 136-152.

Munkert, J., Costa, C., Budeanu, O., Petersen, J., Bertolucci, S., Fischer, G., et al. (2015a). Progesterone 5ß-reductase genes of the Brassicaceae family as function-associated molecular markers. Plant Biology, 17, 1113-1122.

Perez-Bermudez, P., Moya Garcia, A. A., Tunon, I., \& Gavidia, I. (2010). Digitalis purpurea P5ßR2, encoding steroid 5ß-reductase, is a novel defense-related gene involved in cardenolide biosynthesis. New Phytologist, 185(3), 687-700.

Petersen, J., Lanig, H., Munkert, J., Bauer, P., Müller-Uri, F., \& Kreis, W. (2015). Progesterone 5ß-reductases/iridoid synthases (PRISE): gatekeeper role of highly conserved phenylalanines in substrate preference and trapping is supported by molecular dynamics simulations. Journal of Biomolecular Structure and Dynamics, 12, 1-14. doi:10.1080/07391102.2015.1088797.

Ralph, S. G., Chun, H. J., Kolosova, N., Cooper, D., Oddy, C., Ritland, C. E., et al. (2008). A conifer genomics resource of 200,000 spruce (Picea spp.) ESTs and 6,464 high-quality, sequence-finished full-length cDNAs for Sitka spruce (Picea sitchensis). BMC Genomics, 9, 484.

Reß, T., Hummel, W., Hanlon, S. P., Iding, H., \& Gröger, H. (2015). The organicsynthetic potential of recombinant ene reductases: substrate-scope evolution and process optimization. Chemical Catalysis Chemistry, 7, 1302-1311.

Rudolph, K., Bauer, P., Schmid, B., Mueller-Uri, F., \& Kreis, W. (2014). Truncation of $\mathrm{N}$-terminal regions of Digitalis lanata progesterone $5 ß$-reductase alters catalytic efficiency and substrate preference. Biochimie, 101, 31-38.

Sambrook, J., \& Russell, D. W. (2001). Molecular cloning: a laboratory manual (3rd ed.). New York: Cold Spring Harbor Laboratory Press and CSH Laboratory Press.

Savard, L., Li, P., Strauss, S. H., Chase, M. W., Michaud, M., \& Bousquet, J. (1994). Chloroplast and nuclear gene sequences indicate late Pennsylvanian time for the last common ancestor of extant seed plants. Proceedings of the National Academy of Sciences USA, 91, 5163-5167.

Tarrio, R., Ayala, F. J., \& Rodriguez-Trelles, F. (2011). The vein patterning 1 (VEP1) gene family laterally spread through an ecological network. PLoS One, 6, 22279.

Thorn, A., Egerer-Sieber, C., Jäger, C. M., Herl, V., Müller-Uri, F., Kreis, W., et al. (2008). The crystal structure of progesterone 5ß-reductase from Digitalis lanata defines a novel class of short-chain dehydrogenases/reductases. Journal of Biological Chemistry, 283, 17260-17269.

Yang, K. Y., Moon, Y. H., Choi, K. H., Kim, Y. H., Eun, M. Y., Jo, G., et al. (1997). Structure and expression of the AWI 31 gene specifically induced by wounding in Arabidopsis thaliana. Molecular Cells, 7(1), 131-135.

Zerbe, P., \& Bohlmann, J. (2014). Bioproducts, biofuels, and perfumes: Conifer terpene synthases and their potential for metabolic engineering. In R. Jetter (Ed.), Phytochemicals - Biosynthesis, function and application (Recent Advances in Phytochemistry, Vol. 44, pp. 85-107). Switzerland: Springer International Publishers.

\section{Submit your manuscript to a SpringerOpen ${ }^{\odot}$ journal and benefit from:}

- Convenient online submission

- Rigorous peer review

- Immediate publication on acceptance

- Open access: articles freely available online

- High visibility within the field

- Retaining the copyright to your article

Submit your next manuscript at springeropen.com 